\title{
MyRice: pangkalan data pengetahuan padi Malaysia
}

\begin{abstract}
ABSTRAK
Pada masa ini, semua maklumat mengenai penyelidikan padi di Malaysia bertaburan di penerbitan yang berbeza, depositori dan pangkalan data dengan menggunakan pelbagai format digital dan analog. Walaupun terdapat pangkalan data antarabangsa mengenai penyelidikan padi, data tersebut tidak dipautkan dengan dengan geolokasi dan maklumat arkib asas lain yang diperlukan penyelidik untuk membawa penyelidikan ke peringkat yang lebih tinggi. Kami mempersembahkan MyRice, sebuah pangkalan data atas talian Malaysia untuk kegunaan penyelidik dan orang awam. Pembangunan pangkalan data ini akan membolehkan penyelidik saintifik untuk mengesan kembali maklumat penyelidikan padi dan lokasi ia ditanam. Ia dibina menggunakan saluran pendigitalan yang membolehkan pendigitalan pemprosesan berkelajuan tinggi data arkib dan dihubungkan terus dengan enjin carian penerbitan seperti Google Scholar. Fungsi utama termasuk bibliografi, pemetaan dan pemuat naik media untuk penyelidik berkongsi video dan imej. Kami percaya MyRice yang akan menyumbang kepada ekosistem pengetahuan digital di kalangan penyelidik padi tempatan untuk meningkatkan akses kepada pengetahuan dan menjadi tumpuan utama untuk memacu penyelidikan padi Malaysia ke arah sebuah negara berstatus sara diri dalam keterjaminan makanan. Pangkalan data dapat dilayari di http://biodiversity.fbb.utm.my/myrice/.
\end{abstract}

Keyword: Malaysian rice; Database; Crop information; Paddy; Rice 